\title{
Commentary: Valve sparing in aortic root aneurysms-An old promise or a concrete chance?
}

\author{
Lorenzo Di Bacco, MD, Mattia Glauber, MD, and Antonio Miceli, MD, PhD
}

\author{
From the Department of Minimally Invasive Cardiac Surgery, Istituto Clinico Sant'Ambrogio, Milan, Italy. \\ Disclosures: Authors have nothing to disclose with regard to commercial support. \\ Received for publication March 4, 2019; accepted for publication March 5, 2019; available ahead of print April \\ $18,2019$. \\ Address for reprints: Antonio Miceli, MD, PhD, Department of Minimally Invasive Cardiac Surgery, Istituto Clin- \\ ico Sant'Ambrogio, Via Luigi Giuseppe Faravelli 16, Milan, Italy (E-mail: antoniomiceli79@alice.it). \\ J Thorac Cardiovasc Surg 2019;158:1514-5 \\ $0022-5223 / \$ 36.00$ \\ Copyright (c) 2019 by The American Association for Thoracic Surgery \\ https://doi.org/10.1016/j.jtcvs.2019.03.015
}

The restoration of the normal dimension and geometry of aortic root, in particular in patients with genetic collagen disorders, improves survival and reduce incidence of adverse aorta-related events. ${ }^{1}$ For many years, the standard treatment for patients with aortic root aneurysm consisted in aortic root replacement with composite mechanical valve conduit and coronary reimplantation. ${ }^{2}$ Inspired by the mitral experience, reconstructive methods of sparing the aortic valve, associated with replacement of the other component of the aortic root, have been developed with the aim of reducing the risk of thromboembolic and endocarditis events while restoring the normal life expectancy and quality of the life. ${ }^{3}$

In this issue of the Journal, Kunihara and colleagues ${ }^{4}$ report Japanese Cardiovascular Database outcomes of more than 5000 patients undergoing aortic root replacement with valve-sparing root replacement (VSRR) techniques or composite graft-valve (CGV) procedures with mechanical or biological prostheses. Even though VSRR procedures (remodeling and reimplantation techniques) had longer cardiopulmonary bypass and crossclamp times, Kunihara and colleagues $^{4}$ concluded that aortic valve-sparing root replacement was associated with lower morbidity and mortality than CGV. Specifically, the CGV group had a significantly higher incidence of postoperative stroke and prolonged ventilation ( $>72$ hours). Finally, in-hospital mortality was significantly higher in the CGV group than in the VSRR group. ${ }^{4}$

This article by Kunihara and colleagues ${ }^{4}$ offers an important contribution regarding the dilemma of whether replacing the aortic valve is better than sparing it when aortic root replacement is required. With a large sample size, after matching, Kunihara and colleagues ${ }^{4}$ confirm data that VSRR can reduce valve-related complications. Avoiding lifelong oral anticoagulation, valve-sparing procedures reduce the hemorrhagic or thromboembolic adverse events seen with mechanical CGV. Moreover, VRSS may reduce valve dysfunction and reoperation rate

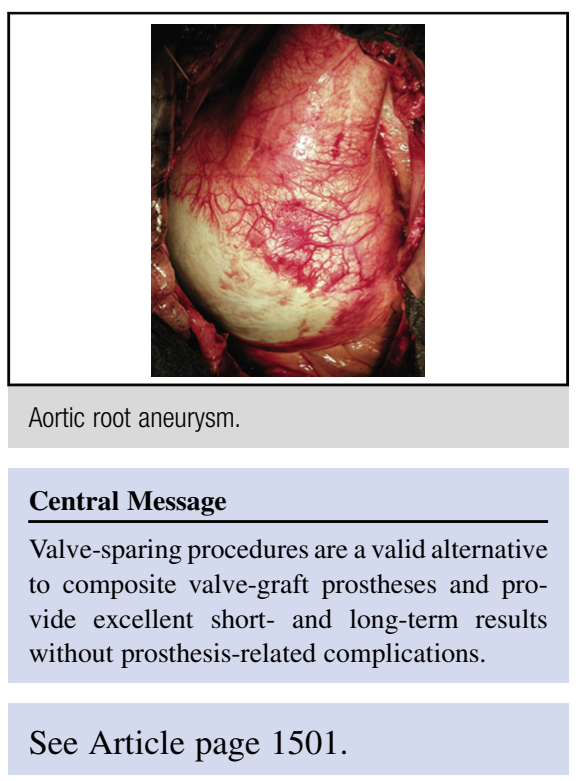

relative to bioprostheses. ${ }^{4}$ The intuitive message that preservation of the native valve is better than replacement has been consistently supported by David and colleagues. ${ }^{5}$ As Kunihara and colleagues ${ }^{4}$ state, in most cases, aortic valve cusps are normal or stretched from annuloaortoectasia, and the valve can recover its normal function once normal root geometry has been restored.

Concerns remain about valve-sparing surgery, however, with regard to indications, reproducibility, success rate, and duration. Since David and Yacoub developed the reimplantation and remodeling techniques, ${ }^{6,7}$ VSRR procedures gained great popularity but never reached a widespread diffusion, with operations on the aortic root not exceeding $15 \%$ of surgical procedures. ${ }^{8}$ These strategies actually remain technically demanding and require a deep knowledge of aortic root and valve geometry, anatomy, and dynamics. ${ }^{9}$ Unsatisfactory VSRR could lead to an early failure. The most common pitfalls are represented by incorrect graft sizing with residual prolapse or restrictive motion of the cusps, organic cusp alterations, or residual prolapse uncorrected or undercorrected.' Schäfers and colleagues ${ }^{10}$ have proposed to address this issue with a dedicated caliper to restore cusp effective height up to 8 to $10 \mathrm{~mm}$. It has been suggested to treat aortic annular base with an internal or external ring, to avoid the risk of new aortic regurgitation, especially in the setting of remodeling technique. 
Finally, this article of Kunihara and colleagues ${ }^{4}$ lacks data regarding echocardiographic information and long-term follow-up. Such information is essential in supporting the conclusion that VSRR has better outcomes than CGV even at long-term.

Historically, the Achilles' heel of valve-sparing operations was long-term durability of these procedures, but now VSRR can be performed with very good intermediate and long-term results. Aortic valve-sparing procedures have been associated with excellent results up to 20 years, especially in young patients. ${ }^{11}$ Similar results have been reported by Lansac's and El Khoury's groups for bicuspid and tricuspid valves. $^{12,13}$

VSRR is a very promising technique, and it is becoming more and more standardized. Its systematic application in the case of aortic root aneurysm with a reparable valve represents the ideal solution, especially for young patients with long life expectancy. A potential failure at long term does not necessarily require an aortic valve replacement. ${ }^{9}$ A new aortic valve repair is possible, offering the chance to minimize the risk of prosthesis-related complications.

\section{References}

1. Bentall H, De Bono A. A technique for complete replacement of the ascending aorta. Thorax. 1968;23:338-9.
2. Coselli JS, Weldon SA, Preventza O, de la Cruz KI, LeMaire SA. Valve-sparing versus composite root replacement procedures in patients with Marfan syndrome. Ann Cardiothorac Surg. 2017;6:692-6.

3. Miceli A, Lio A, Glauber M. The art of repair. J Thorac Cardiovasc Surg. 2017; 153:1021-2.

4. Kunihara T, Ichihara N, Miyata H, Motomura N, Sasaki K, Matsuhama M, et al. Valve-sparing root replacement and composite valve graft replacement in patients with aortic regurgitation: from the Japan Cardiovascular Surgery Database. J Thorac Cardiovasc Surg. 2019;158:1501-11.e6.

5. Ouzounian M, Rao V, Manlhiot C, Abraham N, David C, Feindel CM, et al. Valve-sparing root replacement compared with composite valve graft procedures in patients with aortic root dilation. J Am Coll Cardiol. 2016;68:1838-47.

6. David TE, Feindel CM. An aortic-valve sparing operation for patients with aortic incompetence and aneurysm of the ascending aorta. J Thorac Cardiovasc Surg. 1992;103:617-21; discussion 622.

7. Sarsam MA, Yacoub M. Remodeling of the aortic anulus. J Thorac Cardiovasc Surg. 1993;105:435-8.

8. Stamou SC, Williams ML, Gunn TM, Hagberg RC, Lobdell KW, Kouchoukos NT. Aortic root surgery in the United States: a report from the Society of Thoracic Surgeons database. J Thorac Cardiovasc Surg. 2015;149: 116-22.

9. Van Dyck M, Glineur D, de Kerchove L, El Khoury G. Complications after aortic valve repair and valve-sparing procedures. Ann Cardiothorac Surg. 2013;2: 130-9.

10. Schäfers HJ, Bierbach B, Aicher D. A new approach to the assessment of aortic cusp geometry. J Thorac Cardiovasc Surg. 2006;132:436-8.

11. David TE, David CM, Feindel CM, Manlhiot C. Reimplantation of the aortic valve at 20 years. J Thorac Cardiovasc Surg. 2017;153:232-8.

12. Mastrobuoni S, de Kerchove L, Navarra E, Watremez C, Vancraeynest D Rubay J, et al. Long-term experience with valve-sparing reimplantation technique for the treatment of aortic aneurysm and aortic regurgitation. J Thorac Cardiovasc Surg. 2019;158:14-23.

13. Lansac E, Di Centa I, Sleilaty G, Lejeune S, Khelil N, Berrebi A, et al. Long-term results of external aortic ring annuloplasty for aortic valve repair. Eur J Cardiothorac Surg. 2016;50:350-60. 